\title{
OPTIMALISASI SEKAM PADI BEKAS AYAM PETELUR TERHADAP PRODUKTIVITAS TANAMAN KANGKUNG DARAT (Ipomoea reptans)
}

\author{
Oleh : \\ ACENG ISKANDAR \\ FAKULTAS PERTANIAN UNIVERSITAS GALUH CIAMIS \\ email :acengiskandar2013@gmail.com
}

\begin{abstract}
Abstrak
Dalam peningkatan produksi hortikultura, khususnya sayuran di Indonesia selama ini masih menggunakan sistem pertanian konvensional dengan masukan input luar. Semakin tinggi biaya produksi terhadap pertumbuhan tanaman budidaya, maka akan mengakibatkan semakin tinggi pula masukan input luar seperti pestisida dan pupuk yang diberikan terhadap tanaman.Banyak orang yang menanam kangkung hanya untuk sekedar dikonsumsi sendiri dan melepas hobi bercocok tanam. Namun dalam bercocok tanam sering kali yang menjadikan masalah adalah lahan yang dimiliki tidak dapat ditanami tanaman sesukanya. Jika ingin menanam tanaman, maka dibutuhkan lahan tanah yang cukup luas. Daerah perkotaan saat ini sudah jarang memiliki lahan yang luas yang dapat digunakan sebagai media bercocok tanam. Akan tetapi saat ini banyak berbagai cara yang dapat dilakukan untuk sekedar meluapkan hobi bertanam, salah satunya adalah dengan budidaya kangkung dalam polybag dengan tambahan sekam padi bekas ayam petelur. Polybag adalah menanam tanaman ke dalam kantong plastik hitam. Cara ini dapat digunakan untuk membudidayakan tanaman kangkung, selain tidak membutuhkan lahan yang luas cara ini juga sangat mudah dan hemat untuk dilakukan. Tujuannya adalah untuk meningkatkan hasil tanaman kangkung darat ( Ipomoea reptans) dilakukan untuk mengetahui pengaruh sekam padi yang berasal dari kotoran ayam terhadap pertumbuhan dan produksi kangkung darat (Ipomoea reptans), menggunakan bahan dalam berbudidayanya seperti benih kangkung ( Ipomoea reptans), dan sekam padi yang berasal dari kotoran ayam. Budidaya tanaman kangkung merupakan budidaya tanaman yang menggunakan tahapan-tahapan budidaya seperti langkah awal adalah sediakan media tanam dengan menggunakna polybag,masukan tanah dan campuran sekam padi bekas kotoran ayam ke dalam polybag, usahakan untuk memberikan pupuk organik sehingga tanaman yang akan dihasilkan akan terbebas dari bahan kimia yang berbahaya, pilihlah bibit kangkung yang unggul dengan kualitas yang baik dan tidak busuk atau cacat. Penyemaian bibit kangkung dilakukan ke dalam polybag. Setelah bibit kangkung mulai tumbuh hingga terdapat 3 sampai 5 helai daun lalu pindahkan ke dalam polybag yang sudah disiapkan. Dalam satu polybag dapat menampung sekitar 3 sampai 5 batang kangkung untuk mendapatkan nutrisi yang cukup dan juga dapat tumbuh dengan baik. Lakukan penyiraman dalam waktu 2 kali dalam sehari agar tanah tidak kering dan juga tidak terlalu lembab. Hasil analisis usaha kangkung darat memiliki nilai keuntungan yaitu berdasarkan perhitungan $\mathrm{R} / \mathrm{C}$ ratio yaitu diperoleh 2,59 dengan menggunakan sekam padi bekas kotoran ayam petelur dan yang tidak menggunakan sekam padi ( control) diperoleh R/C ratio yaitu 1,71. Jadi usaha kangkung darat, setiap Rp. 1,- biaya yang dikeluarkan akan mendapatkan penerimaan sebesar Rp. 2,59 (perlakuan dengan menggunakan sekam padi bekas kotoran aya) dan Rp. 1,71 ( pada perlakuan control).
\end{abstract}

Kata Kunci : Optimalisasi, produktivitas, kangkung Darat

\section{PENDAHULUAN}

Dalam peningkatan produksi

hortikultura, khususnya sayuran di Indonesia selama ini masih menggunakan sistem pertanian konvensional dengan masukan input luar. Semakin tinggi biaya produksi terhadap pertumbuhan tanaman budidaya, maka akan mengakibatkan semakin tinggi pula masukan input luar seperti pestisida dan pupuk yang diberikan terhadap tanaman.Tanaman kangkung merupakan tanaman yang menetap yang dapat hidup lebih dari setahun. Tanaman 


\section{A MIMBAR AGRIBISNIS}

ISSN 2460-4321

Volume 1 Nomor 3 - Juli 2016

yang diduga berasal dari kawasan Asia dan Afrika ini meliputi dua jenis yang biasa dibudidayakan petani yakni kangkung darat dan kangkung air.

Kangkung darat memiliki ciri yaitu berdaun panjang dengan ujung runcing dan berwarna hijau keputih-putihan kangkung ini mudah dibedakan dengan kangkung air dari warna bunganya yang putih bersih. Kangkung darat umumnya dijual dalam bentuk cabutan tanaman bersama akarnya. Maka itu, dipasaran kangkung darat diistilahkan dengan kangkung cabut. Tanaman kangkung darat termasuk tanaman dikotil dan berakar tunggang. Akarnya menyebar kesegala arah dan dapat menembus tanah sampai kedalaman $50 \mathrm{~cm}$ lebih. Batang tanaman berbentuk bulat panjang beruas mirip batang bambu. Daun kangkung berwarna hijau tu dibagian atasnya. Tangkai daunnya panjang dan melekat pada setiap ruas batang. (Haryoto, 2009:10)

Banyak orang yang menanam kangkung hanya untuk sekedar dikonsumsi sendiri dan melepas hobi bercocok tanam. Namun tidak sedikit juga para petani yang menanam kangkung sebagai peluang bisnis. Sayuran kangkung memiliki peminat yang cukup banyak, tidak hanya kalangan orang yang memiliki kelas ekonomi rendah, akan tetapi orang yang memiliki kelas ekonomi yang tinggi juga gemar mengonsumsi sayuran kangkung sebagai bahan masakan.Namun dalam bercocok tanam sering kali yang menjadikan masalah adalah lahan yang dimiliki tidak dapat ditanami tanaman sesukanya. Jika ingin menanam tanaman, maka dibutuhkan lahan tanah yang cukup luas. Daerah perkotaan saat ini sudah jarang memiliki lahan yang luas yang dapat digunakan sebagai media bercocok tanam. Akan tetapi saat ini banyak berbagai cara yang dapat dilakukan untuk sekedar meluapkan hobi bertanam, salah satunya adalah dengan budidaya kangkung dalam polybag dengan tambahan sekam padi bekas ayam petelur.Polybag adalah menanam tanaman ke dalam kantong plastik hitam. Cara ini dapat digunakan untuk membudidayakan tanaman kangkung, selain tidak membutuhkan lahan yang luas cara ini juga sangat mudah dan hemat untuk dilakukan. $\begin{array}{cccr}\text { Sekam } & \text { padi } & \text { berfungsi } & \text { untuk } \\ \text { menggemburkan } & \text { tanah } & \text { sehingga } & \text { bisa }\end{array}$ mempermudah akar tanaman menyerap unsur hara di dalamnya. Dengan adanya kotoran ayam pada polybag maka memiliki manfaat bagi tanaman kangkung yaitu bahan organik dalam proses mineralisasi akan melepaskan hara tanaman dengan lengkap ( $, \mathrm{P}, \mathrm{K}, \mathrm{Ca}, \mathrm{Mg}, \mathrm{S}$, serta hara mikro) dalam jumlah tidak tentu dan relatif kecil, meningkatkan daya menahan air (water holding capacity). Sehingga kamampuan tanah untuk menyediakan air menjadi lebih banyak. Kelengasan air tanah lebih terjaga, memperbaiki kehidupan biologi tanah (baik hewan tingkat tinggi maupun tingkat rendah ) menjadi lebih baik karena ketersediaan makan lebih terjamin, dapat meningkatkan daya sangga (buffering capasity) terhadap goncangan perubahan drastis sifat tanah, dan mengandung mikrobia dalam jumlah cukup yang berperanan dalam proses dekomposisi bahan organik.

Menurut pendapat penulis bahwa pemberian pupuk organik khususnya kotoran ayam,dapat memperbaiki struktur tanah karena kotoran ayam banyak mengandung unsur-unsur hara yang sangat diperlukan tanaman khususnya tanaman kangkung yang tumbuh pada tanah tersebut. Sehingga setelah tanah diberi kotoran ayam maka tanaman kangkung yang tumbuh di tanah tersebut dapat tumbuhdengan subur dan cepat tinggi.

Keingintahuan keterkaitan antara sekam padi bekas kotoran ayam dengan pertumbuhan dan produktivitas tanaman kangkung inilah yang membuat penulis mengadakan penelitian lebih lanjut tentang pengaruh sekam padi bekas kotoran ayam terhadap produktivitas tanaman kangkung.

\section{TINJAUAN PUSTAKA}

Tanaman kangkung (Ipomoea reptans Poir ) Merupakan salah satu tanaman yang tidak asing bagi kita. Tanaman kangkung ini sangat mudah di jumpai dan di budidayakan baik di daratan maupun di perairan. Tanaman kangkung berasal dari Asia dan Afrika yang menyebarluas keberbagai benua terutamanya benua Asia yaitu indonesia dan lainnya. Budidaya tanaman kangkung darat (Ipomoea reptans) dilakukan untuk percobaan pengaruh 
sekam padi bekas ayam petelur terhadap pertumbuhan dan produksi kangkung darat (Ipomoea reptans), yang bertujuan untuk mengetahui pengaruh sekam padi bekas ayam petelur terhadap pertumbuhan dan produksi kangkung darat (Ipomoea reptans).

\author{
Klasifikasi Tanaman Kangkung \\ Kindom : Plantae ( Tumbuhan ) \\ Subkingdom : Tracheobionta (Berpembuluh ) \\ Superdivisio :Spermatophyta (Menghasilkan \\ biji) \\ Divisio : Magnoliophyta ( Berbunga ) \\ Kelas : Magnoliapsida (Berkeping dua / dikotil \\ ) \\ Sub kelas: Asteridae \\ Ordo : Solanales \\ Famili : Convovulceae \\ Genus : Ipomoea \\ Spesies : Ipomoea reptan Poir
}

\section{Morfologi Tanaman Kangkung}

Kangkung merupakan tanaman yang sangat tergolong lama tumbuh, tanaman ini memiliki akar tunggang dan bercabang-cabang. Perakaran ini menembus dengan kedalam 60 $100 \mathrm{~cm}$, dan menyebar luas secara mendatar $150 \mathrm{~cm}$ hingga lebih, terutamanya tanaman kangkung pada air.

Batang pada tanaman kangkung bult dan berlubang, berbuku-buku, dan banyak mengandung air. Terkadang buku-buku tersebut mengeluarkan akar tanaman yang serabut dan juga berwarna putih dan ada juga berwarna kecoklatan tua.

Kangkung juga memiliki tangkai dauan melekat pada buku-buku batang dan di keiak batang terdapat mata tunas yang dapat tumbuh cabang baru. Bentuk dauan memiliki ujung runcing dan juga tumpul, permukaan dauan berwarna hijau tua, dan juga berwarna hijau muda.

Bunga pada tanaman kangkung memiliki bentuk terompet dan memiliki dauan mahkota yang berwara putih atau kemerahan. Dan jika menghasilkan buah berbentuk bulat atau oval yang di dalamnya memiliki tiga butit biji. Warna biji tanaman kangkung berwran hitam jika sudah tua dan hijau ketika mudah.
Sekam padi merupakan lapisan keras yang meliputi kariopsis yang terdiri dari dua belahan yang disebut lemma dan palea yang saling bertautan. Pada proses penggilingan beras sekam akan terpisah dari butir beras dan menjadi bahan sisa atau limbah penggilingan. Sekam dikategorikan sebagai biomassa yang dapat digunakan untuk berbagai kebutuhan seperti bahan baku industri, pakan ternak dan energi atau bahan bakar.

Dari proses penggilingan padi biasanya diperoleh sekam sekitar 20-30\% dari bobot gabah. Penggunaan energi sekam bertujuan untuk menekan biaya pengeluaran untuk bahan bakar bagi rumah tangga petani. Penggunaan Bahan Bakar Minyak yang harganya terus meningkat akan berpengaruh terhadap biaya rumah tangga yang harus dikeluarkan setiap harinya.Dari proses penggilingan padi biasanya diperoleh sekam sekitar 20-30\%, dedak antara 8- $12 \%$ dan beras giling antara $50-63,5 \%$ data bobot awal gabah. Sekam dengan persentase yang tinggi tersebut dapat menimbulkan problem lingkungan.Ditinjau data komposisi kimiawi, sekam mengandung beberapa unsur kimia penting seperti dapat dilihat di bawah.

Komposisi kimia sekam padi menurut Suharno (1979) :Kadar air : 9,02\%, Protein kasar 3,03\%, Lemak : 1,18\%, Serat kasar : $35,68 \%$, Abu : 17,17\%, Karbohidrat dasar : 33,71. Manfaat sekam padi yaitu membuat media tanam menjadi kompak (tetap utuh/menyatu meskipun media dikeluarkan dari polybag), menetralkankan $\mathrm{pH}$ tanah (kadar keasaman tanah), menggemburkan tanah, sehingga melancarkan sirkulasi udara dan air dalam tanah, menyerap racun dan mengisolasi penyakit (mensterilkan media), menyimpan air dan akan melepas kembali pada saat tanah kering, arang mempunyai pori yang efektif untuk mengikat dan menyimpan unsur hara dalam tanah untuk disajikan kepada bibit, kapanpun diperlukan, hara tidak mudah tercuci , sehingga kapanpun akan selalu ada, dalam kondisi ibarat makanan siap saji bagi tanaman.

Menurut Ali (1991:394) kotoran ayam merupakan kotoran yang di keluarkan oleh ayam

sebagai proses makananyang disertai urine dan sisa-sisa makanan lainya.Menurut Widodo 


\section{A MIMBBAR}

ISSN 2460-4321

Volume 1 Nomor 3 - Juli 2016

(2008:05) kotoran ayam atau bahan organik merupakan sumber nitrogen tanah yang utama, serta berperan cukup besar dalam memperbaiki sifat fisik, kimia, dan biologis tanah serta lingkungan. Di dalam tanah, pupuk organik akan dirombak oleh organisme menjadi humus atau bahan organik tanah.

Bahan organik berfungsi sebagai "pengikat" butiran primer tanah menjadi butiran sekunder dalam pembentukan agregat yang mantap. Keadaan ini berpengaruh besar pada porositas, penyimpanan dan penyediaan air serta aerasi dan temperatur tanah. Bahan organik dengan $\mathrm{C} / \mathrm{N}$ tinggi seperti jerami dan sekam memberikan pengaruh yang lebih besar pada perubahan sifat-sifat fisik tanah dibanding bahan organik yang telah terdekomposisi seperti kompos.

Meskipun mengandung unsur hara yang rendah, kotoran ayam penting dalam: (1) menyediakan hara makro dan mikro seperti $\mathrm{Zn}, \mathrm{Cu}, \mathrm{Mo}, \mathrm{Co}, \mathrm{Ca}, \mathrm{Mg}$, dan $\mathrm{Si}$, (2) meningkatkan kapasitas tukar kation (KTK) tanah, serta(3) dapat bereaksi dengan ion logam untuk membentuk senyawa kompleks, sehingga ion logam yang meracuni tanaman atau menghambat penyediaan hara seperti $\mathrm{Al}, \mathrm{Fe}$ dan Mn dapat dikurangi.

Menurut Haesono (2009:01) kandungan kotoran ayam adalah sebagai berikut: $2.79 \% \mathrm{~N}$, $0.52 \%$ P2O5, $2.29 \%$ K2O. Maka dalam 1000 $\mathrm{kg}$ (1 ton) kompos akan setara dengan $62 \mathrm{~kg}$ Urea, $14.44 \mathrm{~kg}$ SP 36, dan $38.17 \mathrm{~kg}$ MOP.

\section{METODOLOGI}

Penelitian ini dilaksanakan dengan mengambil lokasi di Desa Sukanagara Rt 005Rw 001 Kecamatan Lakbok Kabupaten Ciamis. Budidaya tanaman kangkung darat ( Ipomoea reptans) dilakukanuntuk mengetahui pengaruh sekam padi bekas kotoran ayam terhadap produktivitas tanaman, menggunakan alat dalam berbudidayanya seperti cangkul, polybag, dan timbangan.

Budidaya tanaman kangkung darat ( Ipomoea reptans) dilakukan untuk mengetahui pengaruh sekam padi yang berasal dari kotoran ayam terhadap pertumbuhan dan produksi kangkung darat (Ipomoea reptans), menggunakan bahan dalam berbudidayanya seperti benih kangkung ( Ipomoea reptans), sekam padi yang berasal dari kotoran ayam.

Budidaya tanaman kangkung merupakan budidaya tanaman yang menggunakan tahapan-tahapan budidaya sepertiangkah awal adalah sediakan media tanam dengan menggunakna polybag,masukan tanah dan campuran sekam padi bekas kotoran ayam ke dalam polybag, usahakan untuk memberikan pupuk organik sehingga tanaman yang akan dihasilkan akan terbebas dari bahan kimia yang berbahaya, pilihlah bibit kangkung yang unggul dengan kualitas yang baik dan tidak busuk atau cacat. Penyemaian bibit kangkung dilakukan ke dalam polybag. Setelah bibit kangkung mulai tumbuh hingga terdapat 3 sampai 5 helai daun lalu pindahkan ke dalam polybag yang sudah disiapkan. Dalam satu polybag dapat menampung sekitar 3 sampai 5 batang kangkung untuk mendapatkan nutrisi yang cukup dan juga dapat tumbuh dengan baik. Lakukan penyiraman dalam waktu 2 kali dalam sehari agar tanah tidak kering dan juga tidak terlalu lembab.

Pemanenan tanaman kangkung darat yang ditanaman dipolybag yang tidak diberi sekam padi dengan tanaman dalam polybag yang berisi sekam bekas kotoran ayam dipisahkan dan ditimbang berapa bobot masingmasing kangkung dengan perlakuan yang berbeda tersebut. Setelah itu tanaman dipanen dan ditimbang berapa bobot setiap tanaman lalu dirata-ratakan, berapa jumlah daun setiap tanaman dan dirata-ratakan. Tanaman dipanen dan ditimbang berapa bobot setiap tanaman lalu dirata-ratakan, berapa jumlah daun setiap tanaman dan dirata-ratakan. Pada tanaman kangkung darat, dipanen dengan cara dicabut yang kemudian akar tanaman dicuci agar bersih dari tanah yang ikut terbawa akar pada saat pemanenan.

Pasca panen tanaman kangkung darat yaitu tanaman kangkung darat dibersihkan dari tanah dan kotoran lainnya menggunakan air, kemudian mengikat batang tanman yang mau dipasarkan. Harga dipasaran kangkung darat perkilogramnya berkisar antara Rp. 15.000 s.d Rp. 17.000 atau pergramnya Rp. 15 s.d Rp. 17. 


\section{Optimalisasi Sekam Padi Bekas Ayam Petelur Terhadap Produktivitas \\ Tanaman Kangkung Darat (Ipomoea Reptans) \\ ACENG ISKANDAR}

\section{HASIL DAN PEMBAHASAN}

Hasil penelitian dalam budidaya tanaman kangkung darat (Ipomoea reptans) menggunakan sekam padi bekas kotoran ayam dalam polybag dilakukan untuk bercocok tanam sering kali yang menjadikan masalah adalah lahan yang dimiliki tidak dapat ditanami tanaman sesukanya. Jika ingin menanam tanaman, maka dibutuhkan lahan tanah yang cukup luas. Daerah perkotaan saat ini sudah jarang memiliki lahan yang luas yang dapat digunakan sebagai media bercocok tanam. Akan tetapi saat ini banyak berbagai cara yang dapat dilakukan untuk sekedar meluapkan hobi bertanam, salah satunya adalah dengan budidaya kangkung dalam polybag dengan tambahan sekam padi bekas ayam petelur. Polybag adalah menanam tanaman ke dalam kantong plastik hitam. Cara ini dapat digunakan untuk membudidayakan tanaman kangkung, selain tidak membutuhkan lahan yang luas cara ini juga sangat mudah dan hemat untuk dilakukan

Hasil penelitian kangkung darat dengan menggunakan sekam padi bekas kotoran ayam dalam polybag diperoleh data sebagai berikut :

Tabel 1 Tinggi TanamanKontrol (P1) dan Tanaman dengan Sekam Padi Bekas Kotoran Ayam (P2)

\begin{tabular}{|c|c|c|c|c|c|c|c|c|c|c|c|}
\hline \multirow{2}{*}{ P1 ( Kontrol) } & \multicolumn{4}{|c|}{ Minggu ke } & \multirow{2}{*}{ Rata-rata } & \multirow{2}{*}{$\begin{array}{c}\text { P2 ( sekam } \\
\text { padi) }\end{array}$} & \multicolumn{4}{|c|}{ Minggu ke } & \multirow{2}{*}{$\begin{array}{c}\text { Rata- } \\
\text { rata }\end{array}$} \\
\hline & 1 & 2 & 3 & 4 & & & 1 & 2 & 3 & 4 & \\
\hline UL 1A & 2 & 7,8 & 34,6 & 71,2 & 28,90 & UL 2A & 2,1 & 7,4 & 35,9 & 81,2 & 31,65 \\
\hline UL 1B & 1,2 & 9 & 26,5 & 60,7 & 24,35 & UL 2B & 2,7 & 13 & 39,6 & 81,5 & 34,20 \\
\hline UL 1C & 1,8 & 7,6 & 34,1 & 72,1 & 28,90 & UL 2C & 1,9 & 12,2 & 44,6 & 71,2 & 32,48 \\
\hline UL 1D & 2,1 & 14 & 35,6 & 65,4 & 29,28 & UL 2D & 3,4 & 8,4 & 25,9 & 61,5 & 24,80 \\
\hline UL 1E & 1,7 & 13,5 & 33,6 & 71,2 & 30,00 & UL 2E & 2,6 & 17,8 & 33,7 & 51,2 & 26,33 \\
\hline UL $1 \mathrm{~F}$ & 1,9 & 7,8 & 34,6 & 71,5 & 28,95 & UL 2F & 2,3 & 8 & 34,6 & 71,5 & 29,10 \\
\hline UL 1G & 3,4 & 9 & 26,8 & 62,2 & 25,35 & UL 2G & 1,9 & 10,2 & 35,5 & 81,2 & 32,20 \\
\hline UL 1H & 1,8 & 7,6 & 34,7 & 72,3 & 29,10 & UL 2H & 3,8 & 17,4 & 33,9 & 21,5 & 19,15 \\
\hline UL 1I & 2,1 & 14 & 35,6 & 65,8 & 29,38 & UL 2I & 2,5 & 15,4 & 34,2 & 61,2 & 28,33 \\
\hline UL 1J & 1,7 & 13,5 & 33,9 & 71,9 & 30,25 & UL 2J & 1,9 & 10 & 35,4 & 81,5 & 32,20 \\
\hline UL 1K & 1,9 & 7,8 & 34,6 & 72,1 & 29,10 & UL 2K & 1,9 & 8,2 & 33,6 & 61,2 & 26,23 \\
\hline UL 1L & 1,8 & 9 & 26,9 & 64,1 & 25,45 & UL 2L & 3,1 & 8,9 & 24,7 & 71,5 & 27,05 \\
\hline UL 1M & 2,1 & 7,6 & 34,3 & 72,8 & 29,20 & UL 2M & 2,4 & 9,4 & 45,9 & 74,2 & 32,98 \\
\hline UL 1N & 1,7 & 14 & 35,6 & 65,4 & 29,18 & UL 2N & 1,9 & 11 & 43,1 & 77,5 & 33,38 \\
\hline UL 10 & 1,9 & 13,5 & 33,9 & 71,3 & 30,15 & UL 2O & 2,8 & 8,2 & 39,3 & 75,2 & 31,38 \\
\hline Rata-rata & 1,94 & 10,38 & 33,02 & 68,67 & 28,50 & Rata-rata & 2,48 & 11,03 & 35,99 & 68,21 & 29,43 \\
\hline
\end{tabular}

Tabel 2 Jumlah Daun Tanaman Kontrol (P1) dan Tanaman dengan Sekam Padi Bekas Kotoran Ayam (P2)

\begin{tabular}{|c|c|c|c|c|c|c|c|c|c|c|c|}
\hline \multirow{2}{*}{ P1 ( Kontrol) } & \multicolumn{4}{|c|}{ Minggu ke } & \multirow{2}{*}{$\begin{array}{l}\text { Rata- } \\
\text { rata }\end{array}$} & \multirow{2}{*}{$\begin{array}{l}\text { P2 ( sekam } \\
\text { padi) }\end{array}$} & \multicolumn{4}{|c|}{ Minggu ke } & \multirow{2}{*}{ Rata-rata } \\
\hline & 1 & 2 & 3 & 4 & & & 1 & 2 & 3 & 4 & \\
\hline UL 1A & 2 & 6 & 13 & 38 & 14,75 & UL 2A & 3 & 10 & 23 & 41 & 19,25 \\
\hline UL 1B & 2 & 7 & 15 & 35 & 14,75 & UL 2B & 4 & 12 & 20 & 45 & 20.25 \\
\hline UL 1C & 2 & 6 & 20 & 31 & 14,75 & UL 2C & 3 & 13 & 19 & 55 & 22,5 \\
\hline UL 1D & 2 & 8 & 22 & 32 & 16 & UL 2D & 4 & 17 & 26 & 47 & 23,5 \\
\hline UL 1E & 2 & 6 & 20 & 35 & 15,75 & UL 2E & 4 & 17 & 28 & 42 & 22,75 \\
\hline UL 1F & 2 & 6 & 12 & 39 & 14,75 & UL 2F & 3 & 10 & 25 & 40 & 19,5 \\
\hline UL 1G & 2 & 5 & 20 & 38 & 16,25 & UL $2 \mathrm{G}$ & 3 & 10 & 26 & 45 & 21 \\
\hline UL 1H & 2 & 5 & 20 & 40 & 16,75 & UL 2H & 4 & 18 & 29 & 43 & 23,5 \\
\hline UL 1I & 2 & 6 & 13 & 38 & 14,75 & UL 2I & 4 & 19 & 30 & 45 & 24,5 \\
\hline UL 1J & 2 & 7 & 15 & 33 & 14,25 & UL 2J & 4 & 16 & 25 & 41 & 21,5 \\
\hline UL 1K & 2 & 7 & 20 & 41 & 17,5 & UL 2K & 3 & 10 & 19 & 35 & 16,75 \\
\hline UL 1L & 2 & 6 & 18 & 38 & 16 & UL 2L & 3 & 11 & 25 & 45 & 21 \\
\hline UL 1M & 2 & 6 & 15 & 31 & 13,5 & UL 2M & 3 & 10 & 25 & 48 & 21,5 \\
\hline UL 1N & 2 & 7 & 21 & 35 & 16,25 & UL 2N & 4 & 16 & 34 & 55 & 27,25 \\
\hline UL 10 & 2 & 8 & 17 & 30 & 14,25 & UL 2O & 3 & 17 & 35 & 45 & 25 \\
\hline Rata-rata & & 6,4 & 17,4 & 35,6 & 15,35 & Rata-rata & 3,47 & 13,73 & 25,93 & 44,80 & 21,98 \\
\hline
\end{tabular}




\section{A MIMBBAR \\ ISSN 2460-4321 \\ Volume 1 - Nomor 3 - Juli 2016} Tabel 3 Berat BasahTanamanKangkung (gr)Tanaman Kontrol (P1) dan Tanaman
Dengan Sekam Padi Bekas Kotoran Ayam (P2)

\begin{tabular}{|c|c|c|c|}
\hline \multirow{2}{*}{ P1 ( Kontrol) } & Minggu ke & \multirow{2}{*}{ P2 ( sekam padi) } & Minggu ke \\
\cline { 2 - 4 } & $\mathbf{4}$ & & $\mathbf{4}$ \\
\hline UL 1A & 55,2 & UL 2A & 95,2 \\
\hline UL 1B & 55,3 & UL 2B & 98,7 \\
\hline UL 1C & 50,4 & UL 2C & 94,9 \\
\hline UL 1D & 48,2 & UL 2D & 100 \\
\hline UL 1E & 55,7 & UL 2E & 99,2 \\
\hline UL 1F & 63,3 & UL 2F & 98,3 \\
\hline UL 1G & 60,7 & UL 2G & 99,7 \\
\hline UL 1H & 54,2 & UL 2H & 86,5 \\
\hline UL 1I & 58,3 & UL 2I & 92,6 \\
\hline UL 1J & 61,3 & UL 2J & 96,3 \\
\hline UL 1K & 54,5 & UL 2K & 91,2 \\
\hline UL 1L & 55,4 & UL 2L & 95,3 \\
\hline UL 1M & 59 & UL 2M & 94,6 \\
\hline UL 1N & 62,1 & UL 2N & 99,3 \\
\hline UL 1O & 65,8 & UL 2O & $\mathbf{1 4 3 2 , 1}$ \\
\hline Jumlah & $\mathbf{8 5 9 , 3 5}$ & Jumlah & $\mathbf{9 5 , 4 7}$ \\
\hline Rata-rata & $\mathbf{5 7 , 2 9}$ & Rata-rata & \\
\hline
\end{tabular}

Dari data tersebut menunjukan perbedaan berat tanaman tanpa sekam padi kotoran ayan dengan tanaman kangkung bersekam padi bekas kotoran ayam pada setiap perlakuan dan ulangan. Hal ini disebabkan karena dengan penambahan sekam padi maka tanaman kangkung akan membuat tanaman menjadi kompak (tetap utuh/menyatu meskipun media dikeluarkan dari polybag), menetralkankan $\mathrm{pH}$ tanah (kadar keasaman tanah), menggemburkan tanah, sehingga melancarkan sirkulasi udara dan air dalam tanah, menyerap racun dan mengisolasi penyakit (mensterilkan media), menyimpan air dan akan melepas kembali pada saat tanah kering, arang mempunyai pori yang efektif untuk mengikat dan menyimpan unsur hara dalam tanah untuk disajikan kepada bibit, kapanpun diperlukan, hara tidak mudah tercuci, sehingga kapanpun akan selalu ada, dalam kondisi ibarat makanan siap saji bagi tanaman. Dengan tambahan kotoran ayam maka kotoran ayam atau bahan organik merupakan sumber nitrogen tanah yang utama, serta berperan cukup besar dalam memperbaiki sifat fisik, kimia, dan biologis tanah serta lingkungan. Di dalam tanah, pupuk organik akan dirombak oleh organisme menjadi humus atau bahan organik tanah.

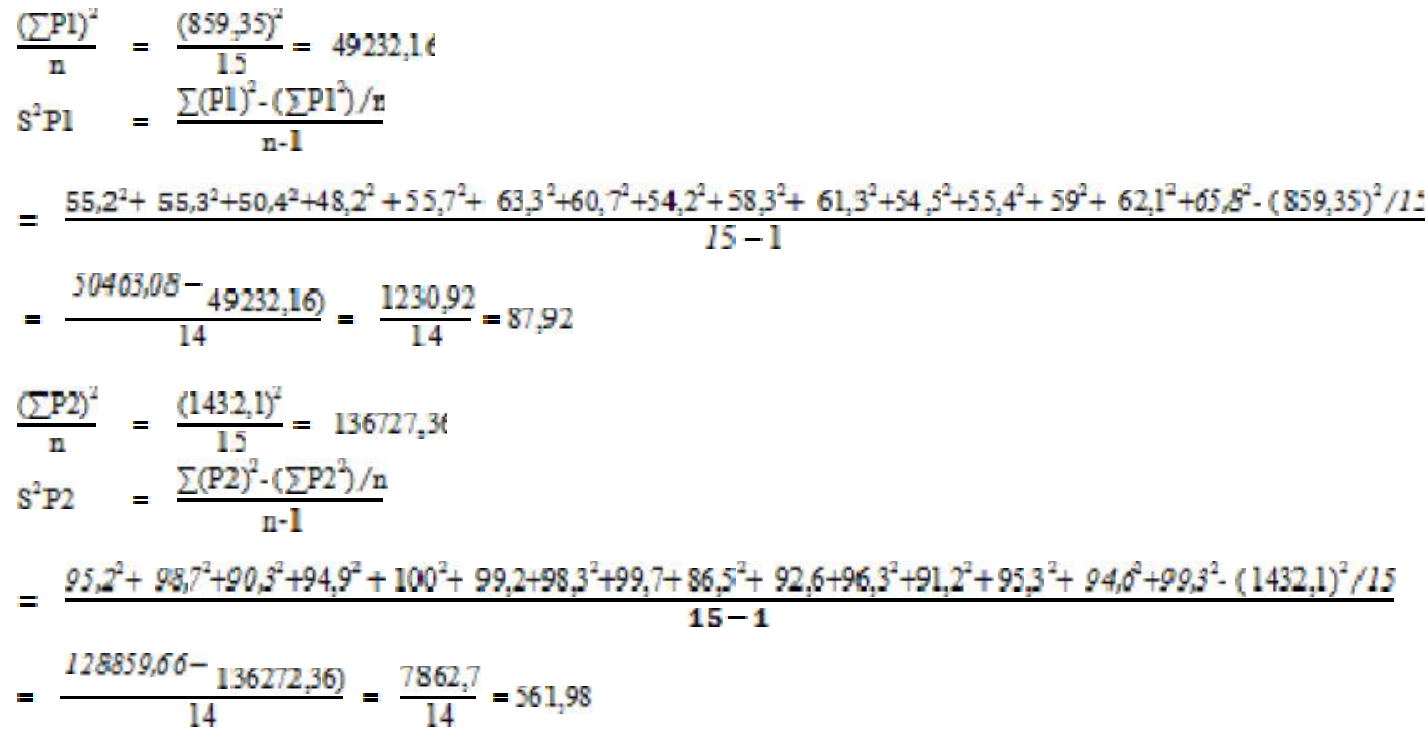




\section{ACENG ISKANDAR}

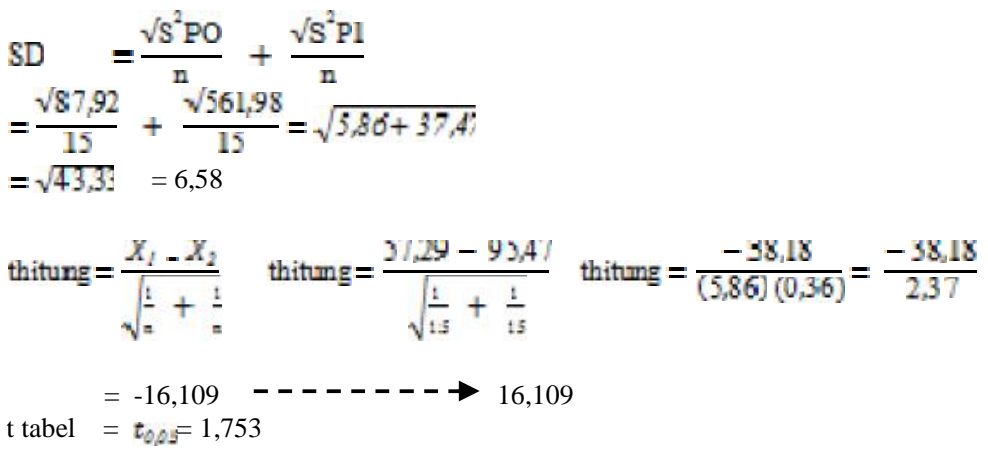

Hipotesa : Karena $\mathrm{t}$ hitung $(16,109) \geq \mathrm{t}$ tabel (1,753) maka HO ditolak H1 diterima. Artinya terdapat perbedaan yang sangat nyata dari kedua perlakuan pada tanaman kangkung dengan pemberian sekam padi bekas kotoran ayam petelur dengan tanaman kangkung tanpa sekam padi bekas kotoran ayam petelur.

Tabel 4 Analisis Usaha Produksi Kangkung Dengan Sekam Padi Bekas Ayam Petelur

\begin{tabular}{|c|c|c|c|}
\hline \multirow{2}{*}{ No } & \multirow{2}{*}{ Uraian } & \multicolumn{2}{|c|}{ Perlakuan } \\
\hline & & $P(1)$ & (P2) \\
\hline $\bar{A}$ & $\begin{aligned} \text { Output } & \\
1 . & \text { Hasil utama kangkung } \\
\bullet & 15 \times \text { x } 3 \text { x 57,29 gram }) @ \text { Rp. 15 } \\
\bullet & 15 \times(3 \times 95,47 \text { gram }) @ \text { Rp.15 } \\
\text { Jumlah } & \end{aligned}$ & $\begin{array}{l}\text { Rp. } 38.671 \\
\text { Rp. } 38.671\end{array}$ & $\begin{array}{l}\text { Rp. } 64.443 \\
\text { Rp. } \mathbf{6 4 . 4 4 3}\end{array}$ \\
\hline B & $\begin{aligned} \text { Input } & \\
\text { 1. } & \text { Biaya produksi } \\
\text { - } & \text { Polybag ukuran } 30 \text { x } 30(15 \times 3 \times \text { Rp. } 450) \\
\text { - } & \text { Benih kangkung var. Bangkok (15 x } 3 \text { x Rp. 22) } \\
\text { - } & \text { Pupuk/ Sekam padi bekas kotoran ayam ( } 4 \text { kg x } 3 \times \text { Rp 300) } \\
\text { - } & \text { Pestisida } \\
\text { Jumlah } & \end{aligned}$ & $\begin{array}{l}\text { Rp } 20.250 \\
\text { Rp. } 990 \\
\text { Rp. } 0 \\
\text { Rp. } 15.000 \\
\quad \text { Rp. } \mathbf{3 6 . 2 4 0}\end{array}$ & $\begin{array}{l}\text { Rp. } 20.250 \\
\text { Rp. } 990 \\
\text { Rp. } 3.600 \\
\text { Rp. } 15.000 \\
\quad \text { Rp. } 39.840\end{array}$ \\
\hline \multirow[t]{4}{*}{$\mathrm{C}$} & 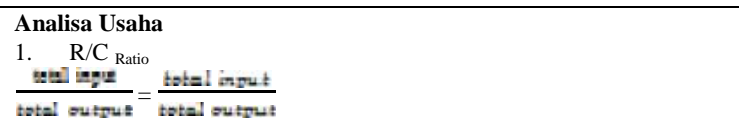 & 1,71 & 2,59 \\
\hline & 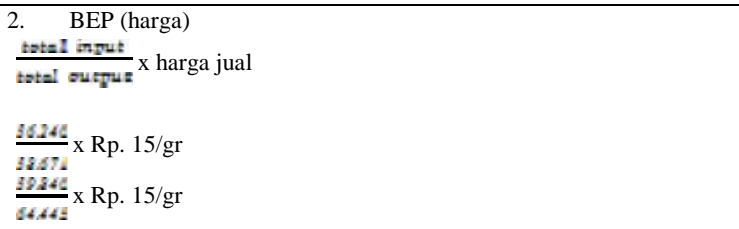 & Rp.14.5 & Rp. 9.27 \\
\hline & 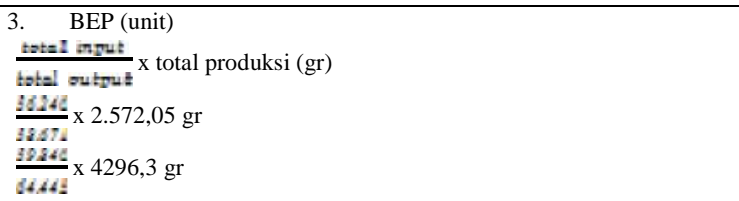 & $2.410,4$ & $2.656,1$ \\
\hline & 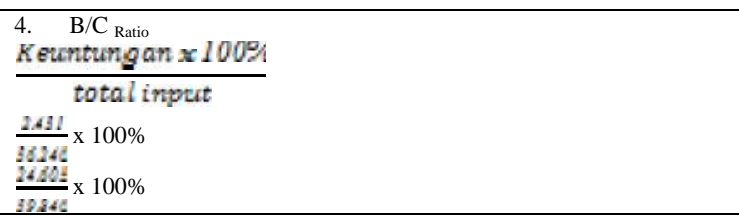 & 6,71 & 61,75 \\
\hline
\end{tabular}




\section{AIMBAR AGRIBISNIS \\ ISSN 2460-4321}

Volume 1 - Nomor 3 - Juli 2016

Berdasarkan analisis usaha pengaruh sekam padi bekas kotoran ayam terhadap produktivitas tanaman kangkung darat maka dapat dijelaskan bahwa usaha budidaya kangkung darat memiliki nilai keuntungan dan layak untuk dikembangkan yaitu berdasarkan perhitungan $\mathrm{R} / \mathrm{C}$ ratio yaitu diperoleh 2,59 dengan menggunakan sekam padi bekas kotoran ayam petelur dan yang tidak menggunakan sekam padi ( control) diperoleh $\mathrm{R} / \mathrm{C}$ ratio yaitu 1,71 . Jadi usaha kangkung darat, setiap Rp. 1,- biaya yang dikeluarkan akan mendapatkan penerimaan sebesar Rp. 2,59 (perlakuan dengan menggunakan sekam padi bekas kotoran aya) dan Rp. 1,71 ( pada perlakuan control).

Sedangkan menurut perhitungan $\mathrm{B} / \mathrm{C}$ ratio diperoleh hasil untuk perlakuan pertama (control) diperoleh hasil 6, 71\% dan pada perlakuan kedua diperoleh $61,75 \%$ yang artinya $\mathrm{B} / \mathrm{C}$ ratio yang diperoleh $>$ dari 1 maka uasaha kangkung darat dengan menggunakan sekam padi bekas kotoran ayam layak untuk dilaksanakan dan dikembangkan karena memiliki nilai keuntungan.

Berdasarkan hasil pengamatan pada masyarakat, diperoleh penjelasan bahwa masyarakat lebih menyukai kangkung darat dibanding kangkung air untuk dikonsumsi dan untuk budidaya produksi, dikarenakan proses budidayanya tidak memerlukan proses yang rumit, lahan pun tidak memerlukan lahan yang luas dengan menggunakan polybag pun bisa dilakukan. Kangkung darat untuk konsumsi memiliki manfaat yaitu menurut Linawati (2003), kangkung justru dapat menghilangkan rasa kantuk. Kandungan zat besi yang tinggi pada kangkung dapat membuat konsentrasi otak menjadi meningkat. Zat besi merupakan komponen terpenting dalam pembuatan sel-sel darah merah. Dengan meningkatnya produksi sel-sel darah merah, aliran oksigen ke seluruh tubuh, terutama ke otak, ikut meningkat sehingga membuat tubuh menjadi lebih segar dan bugar.

\section{PENUTUP}

Meningkatkan hasil dalam budidaya tanaman kangkung darat (Ipomoea reptans) dengan mengoptimalkan penggunaaan sekam padi bekas kotoran ayam dalam polybagmemiliki nilai keuntungan dan layak untuk dikembangkan yaitu berdasarkan perhitungan $\mathrm{R} / \mathrm{C}$ ratio yaitu diperoleh 2,59 dengan menggunakan sekam padi bekas kotoran ayam petelur dan yang tidak menggunakan sekam padi ( control) diperoleh $\mathrm{R} / \mathrm{C}$ ratio yaitu 1,71. Jadi usaha kangkung darat, setiap Rp. 1,- biaya yang dikeluarkan akan mendapatkan penerimaan sebesar Rp. 2,59 (perlakuan dengan menggunakan sekam padi bekas kotoran aya) dan Rp. 1,71 ( pada perlakuan control).

\section{DAFTAR PUSTAKA}

Ali,Lukman 2001 Kamus Besar Bahasa Indonesia Departemen Pendidikan Nasional

Haesono. 2009. Terobosan Teknologi Pemupukan Dalam Era Pertanian Organik. Yoyakarta: Kanisius.

Haryoto. 2009. Bertanama Kangkung Raksasa Di perkarangan rumah. Yogyakarta : Kanisius

Pranata, ayub S. 2010. Meningkatkan Hasil Panen Dengan Pupuk Organik. Jakarta : Agromedia Pustaka

Rukmana, rahmat. 2005. Bertanaman Sayuran Di Pekarangan. Yogyakarta : Kanisius

Suharno. 1979. Sekam Padi Sebagai Sebagai Sumber Energi Alternatif. (www.smallcrab.com/).

Sutanto,rahman. 2002. Penerapan pertanian Organik,Pemasyarakatan dan Pengembangan. Yogyakarta : Kanisius

Widodo. 2008. Pupuk Organik dan Pupuk Hayati. Jawa Barat: Balai BesarPenelitian dan Pengembangan Sumberdaya Lahan Pertanian. 